\title{
EL RETABLO DE SAN ESTANISLAO DE KOSTKA EN SAN LUIS DE LOS FRANCESES DE SEVILLA*
}

\author{
RAFAel García MAHÍQUeS ${ }^{1}$ \\ Universitat de València
}

Al Dr. Pedro Campa, por aquella porción de san Estanislao

\begin{abstract}
El templo de San Luis de los franceses de Sevilla, construido a lo largo de las primeras décadas del siglo XVIII, dispone de un complejo programa visual. El retablo de San Estanislao de Kostka ocupa una importante capilla, en paralelo a la de San Francisco de Borja. Como todo retablo, cumple dos funciones: la contemplativa, o conductora de la oración a través de su imagen conceptual, y la formativa por medio del discurso visual desplegado en las calles laterales y el ático. Se afronta el análisis de ambas facetas mediante una aproximación a sus fuentes literarias y emblemáticas.

Palabras Clave: imagen conceptual; tipo iconográfico; emblemática; jeroglífico; hagiografía.
\end{abstract}

THE ALTARPIECE OF ST. STANISLAUS OF KOSTKA IN SAN LUIS DE LOS FRANCESES OF SEVILLE

The temple of San Luis de los Franceses of Seville, built throughout the first decades of the 18th century, offers a complex visual program. The altarpiece of St. Stanislaus of Kostka is located in an important chapel, parallel to that of St. Francis Borgia. Like any altarpiece, it has two functions: the contemplative, in the sense that it guides prayer through its conceptual image, and the formative by means of the visual discourse displayed in the lateral and pinnacle panels. The analysis of both facets is carried out through an examination of their literary and emblematic sources.

Key Words: Conceptual Image; Iconographic Type; Emblematics; Hieroglyph; Hagiography.

Cómo citar este artículo / Citation: García Mahíques, Rafael (2020) "El Retablo de San Estanislao de Kostka en San Luis de los franceses de Sevilla”. En: Archivo Español de Arte, vol. 93, núm. 371, Madrid, pp. 239-258. https:// doi.org/10.3989/aearte.2020.16.

El complejo de San Luis de los franceses fue planificado como el noviciado central de toda la Provincia Bética. Los jesuitas se instalaron en la casa en 1603, y en enero de 1604 se llevó a cabo la primera misa en la primitiva iglesia y consiguiente inauguración de la casa. En 1610 llegaron los primeros novicios, congregándose los procedentes de Montilla y de Osuna. La iglesia que nos ha llegado a la actualidad de este noviciado había comenzado a ser construida en 1699 , culminando en 1731, con algún período intermedio de inactividad ${ }^{2}$. Su consagración definitiva se produjo el 25 de enero de 1733.

* El presente estudio se enmarca en el proyecto "Los tipos iconográficos de la tradición cristiana", financiado por el Ministerio de Economía, Industria y Competitividad (HAR2015-65176-P).

1 mahiques@uv.es / ORCID iD: https://orcid.org/0000-0002-9889-7228.

2 Fue publicada una memoria de las fiestas relativas a la dedicación del templo y de la casa de probación, y otra con el sermón a cargo de Pedro del Busto en el día de la festividad de san Estanislao de Kostka: Anónimo, 1731; Busto, 1731. Para las precisiones cronológicas e históricas, me baso fundamentalmente en la actualizada monografía de 


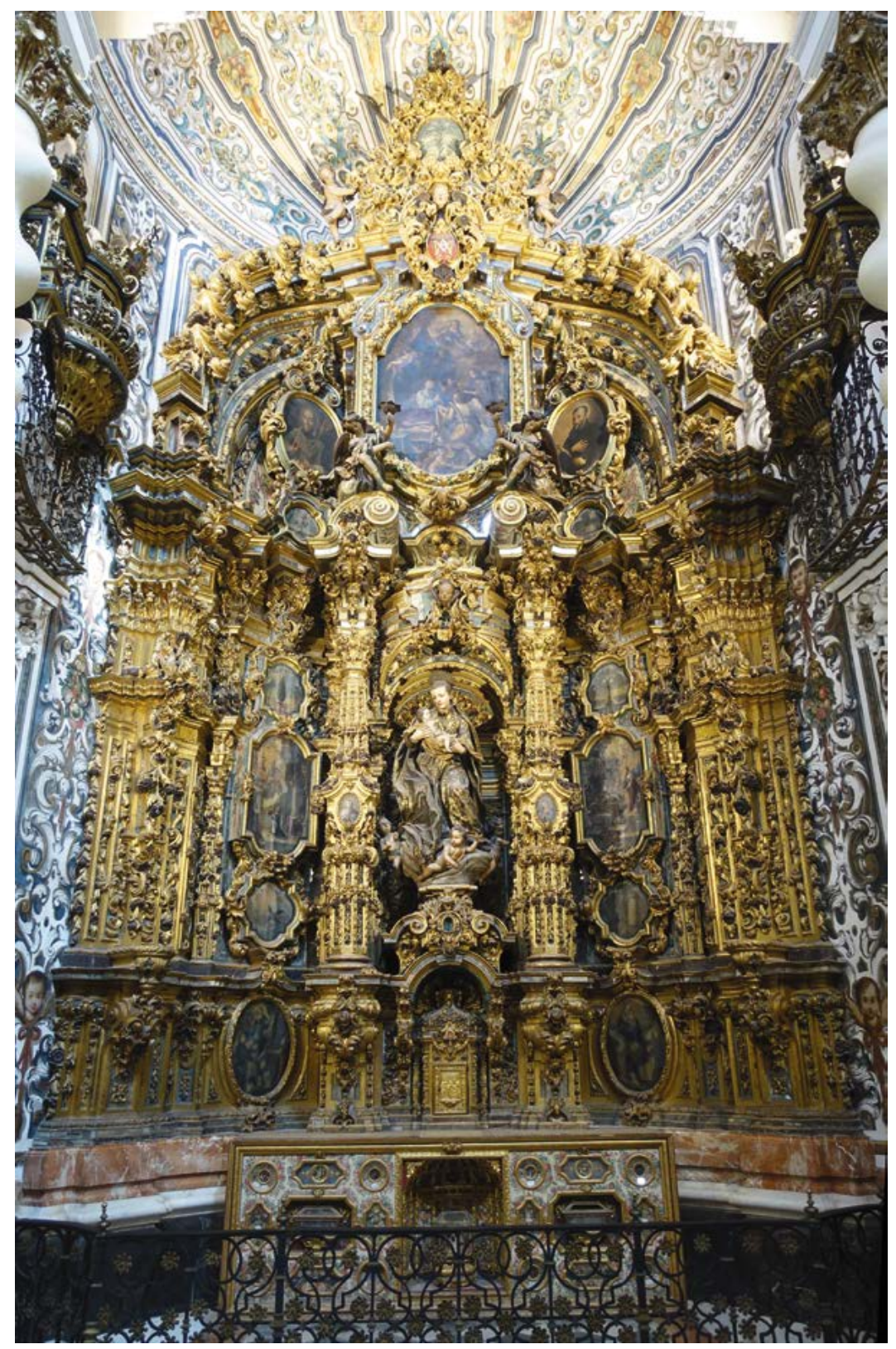

Fig. 1. Sevilla. Iglesia de san Luis de los franceses, Retablo de san Estanislao de Kostka.

Una figura esencial fue el rector Jerónimo de Ariza, considerado como el mentor de toda la retórica visual desarrollada en el templo, tal como cabe deducir de una inscripción, así como de otras fuentes contemporáneas ${ }^{3}$. En su primer rectorado (1727-1732), debieron concluir los deta-

Ravé, 2010: 15-35. Me seguiré remitiendo a la misma en cuanto a los diferentes datos sobre localización de las obras artísticas de este noviciado: dataciones, autorías, etc. También han sido consultados los estudios de Camacho Martínez, 1989: 202-213; Banda y Vargas, 1977 y 2004; y Gómez Piñol, 2004. Desde el punto de vista arquitectónico, para una visión sobre el conjunto de estudios dedicados al noviciado, debe de ser consultado Morales, 2012: 349 y ss. Así también, Rodríguez de Ceballos, 2004: 57 y ss.

${ }^{3}$ La citada inscripción dice así: "Se empezó esta obra a cinco de abril siendo discurrida la idea y pensamiento de toda ella por el sutil y nunca bien alabado ingenio del M.R.P.M. Geronimo de Hariza exprovincial de esta Provincia de 
lles arquitectónicos finales y parte del programa visual, como las esculturas de las ocho VirtudesBienaventuranzas y los Padres de la Iglesia. Es también en este momento cuando se hace el encargo de los retablos, que al menos serían el central y los dos laterales. Algo posteriores, al parecer, son los cuatro retablos menores situados en los machones de sostén de la cúpula: San Ignacio, San Francisco Javier, San Luis Gonzaga y San Juan Francisco Régis. En su segundo rectorado (1736-1742), Ariza pudo rematar la obra encargando las pinturas murales de la iglesia a Domingo Martínez. En 1740 se fecha la pintura mural de los ábsides laterales y en 1742 se termina la de la exedra de entrada. Acaba también el dorado de los retablos y los frontales de los altares, colocados estos últimos en 1739.

En el presente estudio nos vamos a centrar solamente en el análisis del retablo de San Estanislao de Kostka [fig. 1], que junto con el de San Francisco de Borja, ambos ocupan las dos capillas o ábsides laterales de la iglesia, los más importantes tras el retablo del altar mayor. Estos dos retablos se montarían entre 1731 y 1733, año de la consagración definitiva de la Iglesia. El diseño es obra, junto con el retablo principal, del taller de Pedro Duque Cornejo ${ }^{4}$. En concreto, a este escultor corresponde la talla del retablo de San Estanislao de Kostka y las dos imágenes centrales de San Estanislao de Kostka y San Francisco de Borja. En lo correspondiente a la pintura del retablo es obra del taller de Domingo Martínez, aunque no hay que descartar tampoco la intervención del mismo Duque Cornejo y su taller, cuya actividad artística no se limitó únicamente a la talla de imágenes y retablos. En cualquier caso, la calidad de la pintura es también bastante desigual en determinadas partes.

Obviamos aquí un análisis formal y estilístico, aspecto del que principalmente se han ocupado los diferentes estudios realizados hasta hoy. Baste advertir que, así como desde el punto de vista formal, la estructura de un retablo resulta siempre fácil de comprender - la imagen de la hornacina, la predela, las calles laterales, el ático, etc.- - desde el punto de vista visual — significante y discursivo - no resulta tan fácil hablar de estructuras organizadas de un modo estable. En cada caso singular, el aparato retórico-visual funciona de un modo distinto y específico.

La imagen que preside cualquier retablo es siempre conceptual, es decir una representación atemporal del santo destinada, desde el punto de vista cristiano, a ejercer de vínculo íntimo o místico —en el más puro sentido neoplatónico-, entre el alma de quien se acerca con ánimo contemplativo y el santo, morador del paraíso de los bienaventurados. Dicha imagen ha de poseer la cualidad de atraer por medio de las emociones y la belleza para transportar al orante al ámbito de lo sublime que va más allá de la belleza física, la cual ha servido de reclamo o puerta que ha mostrado el camino. Pero al mismo tiempo, la imagen cristiana cumple una segunda función: ser también objeto al servicio de la formación del cristiano, y es especialmente aquí donde se explica mejor la funcionalidad del conjunto de imágenes como recurso de lo que comúnmente denominamos "retórica visual".

Es muy importante que recalemos en este último concepto, ya que es especialmente durante el Barroco cuando este ejercicio toma el máximo desarrollo. No debemos de olvidar que la retórica, la disciplina de la elocuencia del discurso, se apoya también en el medio visual, actuando ambos medios - la palabra y la imagen - concertadamente en el ejercicio de la función comunicativa y persuasiva. Un retablo, pues, lo entendemos como un diagrama conceptual o como un discurso verbo-visual estructurado. Es en este plano donde encajará, para el caso que nos ocupa, la función de la emblemática, recurso por excelencia de dicha retórica verbo-visual.

\footnotetext{
Andalucía y rector dos veces de esta casa y siendo dirigida su execución por el insigne D. Domingo Martínez (...) en Sevilla a 6 de agosto de 1743" (Camacho Baños, 1935: 34). Herrera García admite el testimonio del P. García, quien llegó a decir: "todo quanto se mira, y admira en el noviciado de San Luis, al Padre Geronymo de Hariza se debe como agente, como director, como artífice, como a destinado por Dios, para una obra que muchas veces vista dexa nueva materia al aplauso, y admiración (...)" (Herrera, 2010: 100).

${ }^{4}$ La vinculación de Pedro Duque Cornejo — nieto de Pedro Roldán y sobrino de Luisa, la Roldana - con el noviciado se remonta a 1716, momento en que se tiene que recluir en esta institución cuando fue embargado y perseguido por la justicia. En esos momentos se pudo planear su trabajo en la Capilla doméstica o Capilla de los novicios, donde realizó su retablo, laboratorio de ideas para las propuestas que aplicará al templo principal (Ravé, 2010: 128).
} 
En síntesis, el retablo, aparte de ejercer una función estimulante del acto contemplativo o místico, también ejerce una función instructiva como vehículo de conceptos en manos del mentor o del predicador. Los retablos no están concebidos para que el espectador interprete libremente. Éste puede ser cautivado primariamente por la belleza y la admiración, pero tiene que ser el predicador o educador quien le irá guiando para una lectura formativa como una mnemotecnia proyectada en las imágenes. No será hasta la llegada de la Modernidad cuando se abandone la retórica verbo-visual y una nueva estética conciba las imágenes como algo dirigido directamente al espectador sin intermediación.

\section{Discurso visual del retablo}

Trataremos aquí de aproximar la construcción discursiva de este retablo por la vía de extensionalizar su contenido con el auxilio de fuentes literarias y visuales concretas. Para ello conviene, aunque brevemente, perfilar la figura de san Estanislao de Kostka (1550-1568). De acuerdo con las primeras biografías ${ }^{5}$, Estanislao, natural de Zacroczym (Polonia), fue hijo de una familia acomodada. No se sabe mucho de su infancia, pero debió recibir, con sus hermanos, una educación estrictamente católica. A los 13 años continuó su instrucción en Viena, junto con su hermano Pablo, en el instituto imperial regido por los jesuitas. En esta etapa, dedicaba mucho tiempo a la oración, con mortificaciones y ayunos y, según el proceso de beatificación, en declaración de su hermano, experimentó estados de inconsciencia en la iglesia. Oraba diariamente y asistía a misa. Obligado a permanecer en la cama por razones de salud, y habiéndosele negado el viático - según algunas fuentes, por residir circunstancialmente en casa de un prohombre luterano-, dijo haber tenido la visión de santa Bárbara, acompañada de dos ángeles que le dieron la comunión. Más tarde también tuvo la visión de la Virgen con el Niño, quien, curándolo, le instó a ingresar en la Compañía de Jesús. En ello tuvo la oposición familiar. Decidió abandonar a su familia y por su cuenta anduvo hasta Dilinga, en donde Pedro Canisio, provincial jesuita, dirigió su primera probación, y lo envió posteriormente a Roma, donde fue recibido por Francisco de Borja, general de la Compañía de Jesús, aceptándose su solicitud el 28 de octubre de 1567. Un año después, con su segunda probación, hizo los votos. El padre, cuando supo la noticia, envió a Roma al mayor de sus hijos con la orden de traérselo de vuelta a casa, pero cuando Pablo llegó, Estanislao había muerto ya de malaria, con 18 años. En efecto, en vísperas de la fiesta de san Lorenzo, empeoró la salud de Estanislao y vio que su fin estaba próximo. Escribió una carta a la Virgen María rogándole que lo llamara para celebrar en el Cielo el aniversario de su Asunción. Murió en la madrugada del 15 de agosto, envuelto en pías declaraciones a Dios, los santos y la Virgen María. Fue beatificado el 14 de agosto de 1606, y canonizado por Benedicto XIII el 31 de diciembre de 1726 .

Pocos años después de la canonización, en 1731, estaba ya instalado el retablo en el noviciado de San Luis de los franceses. Su programa visual lo debió inspirar el rector Jerónimo de Ariza basándose en los grabados sobre la vida del santo publicados por los jesuitas de la casa de Dilinga en 1727, en esta misma ciudad bávara, lo que nos pone también el umbral temporal inferior para la datación de éste (Sancti Stanislai Kostka S.J., 1727). Más que una biografía en sí, esta obra es una hagiografía en todo su pleno sentido, es decir, una reconstrucción idealizada de la vida del santo orientada a la formación de novicios, mediante un conjunto de 40 láminas grabadas, encabezando sus respectivas disertaciones morales, obedeciendo cada una de éstas a la misma estructura. En primer lugar, una imagen (grabado) o construcción visual que consta de un cuadro de carácter narrativo sobre un episodio concreto de la vida de Estanislao, coronado

\footnotetext{
5 En el año de su muerte fueron escritas "vidas" por los jesuitas Fazio — que permanece manuscrita—y Warsewitz (Bruselas, 1895). En esencia, lo que aportan es recogido en diferentes biografías posteriores, de las cuales, la más completa corresponde a Ubaldini, 1890-1897. Para el presente trabajo nos interesan especialmente las anteriores a la fecha de construcción de este retablo: Ribadeneira, 1609; Sacchini, 1609; Bartoli, 1681.
} 


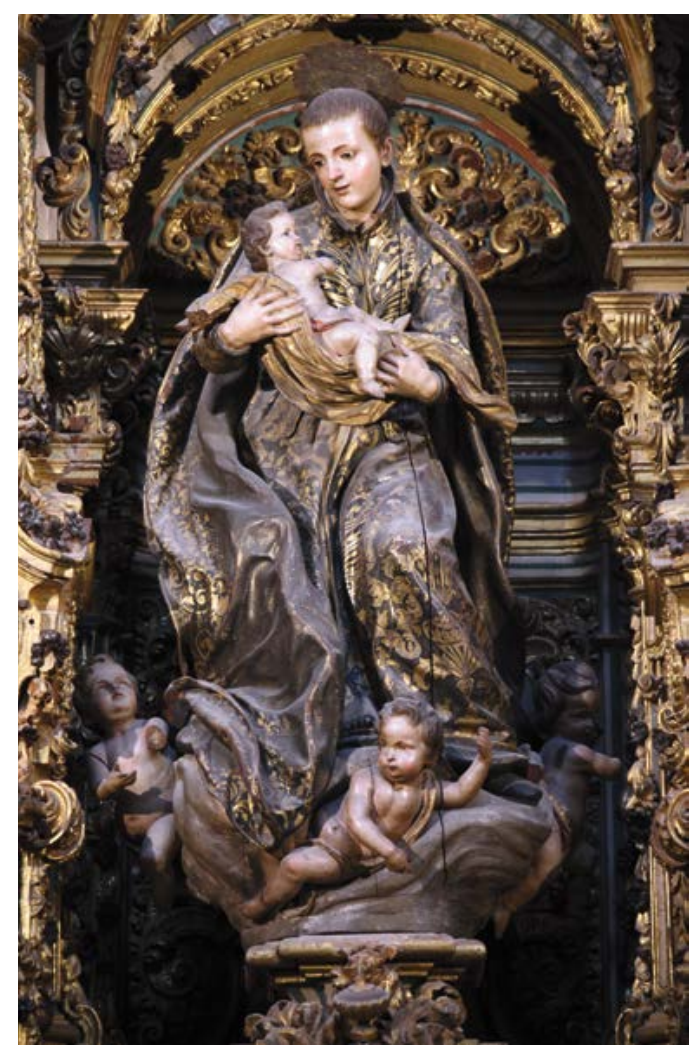

Fig. 2. Imagen conceptual de san Estanislao de Kostka. Pedro Duque Cornejo, 1731.

con un emblema o jeroglífico con un texto sintético en la parte inferior. En segundo lugar, un texto dividido en tres partes: I, Explicatio Symboli en donde se explica el sentido del emblema; II, Prosecutio Vitae, donde se narra el episodio de la vida; y III, Doctrina Moralis, en donde se ofrecen reflexiones edificantes para el lector. La última lámina $\left(\mathrm{n}^{\circ}\right.$ $\mathrm{XL}$ ) representa la apoteosis del santo y encabeza la parte dedicada a los milagros obrados por el santo en las causas de beatificación y canonización.

El retablo, de acuerdo con los criterios expuestos, está estructurado en diferentes hitos o temas, comenzando con la imagen de la hornacina central, punto focal que concentra la atención del espectador, centro devocional. A su alrededor se disponen diferentes temas, organizados con criterios biográficos - episodios objetivos, contenidos en las biografías-y pseudo-biográficos o ideales, conformando en su conjunto un discurso verbo-visual.

\section{Imagen conceptual de San Estanislao de Kostka}

Pedro Duque Cornejo diseñó una bellísima imagen escultórica de carácter conceptual dotada de un estudiado movimiento corporal, sostenida por una masa de nube con ángeles infantes portadores de atributos, que sugiere el ámbito celeste [fig. 2]. El santo aparece en trato místico con el Niño Jesús, como un diálogo expresado por las miradas. Los tres ángeles que se mueven en la base de nubes son portadores de unos atributos hoy perdidos, pero a juzgar por los dibujos preparatorios, no debió faltar la azucena ${ }^{6}$.

Como ya señalé en su día, remitiéndome también a E.H. Gombrich, por imagen conceptual se entiende originariamente toda la producción artística pre-griega que dispone en imágenes o diagramas icónicos determinados conceptos mentales. La revolución artística griega consistió justamente en la superación de esto por la vía de pretender narrar acontecimientos por medio de las imágenes, lo cual suponía concebir las imágenes como algo ajustado a las coordenadas espacio-tiempo. La imagen conceptual, en cambio, expresa conceptos dentro de un marco ajeno al espacio-tiempo. Esta clase de imagen no terminó despareciendo tras la revolución griega, antes bien se recupera cuando la imagen tiene que servir como vía para articular conceptos o argumentos discursivos - doctrinales, morales, políticos, etc. Sería el caso del cristianismo en su primera etapa.

Es así como puede entenderse que, en un retablo, la imagen principal sea esencialmente una imagen conceptual, fuera de la espacio-temporalidad narrativa y definida icónicamente mediante atributos. En este sentido, la cuestión está también en el hecho de que el Barroco tiende a introducir verosimilitud narrativa en esta clase de imágenes, lo que parece romper dicha atemporali-

\footnotetext{
${ }^{6}$ A juzgar por la posición de las manos del ángel central — no presente en los dibujos— permite tal cosa sin temor a equivocarnos. Los citados dibujos preparatorios pertenecen al Álbum Jaffe, hoy en el Metropolitan Museum de Nueva York. García Luque, 2017: 83; 2018: 44. Martínez del Valle, 2017: 439-443.
} 

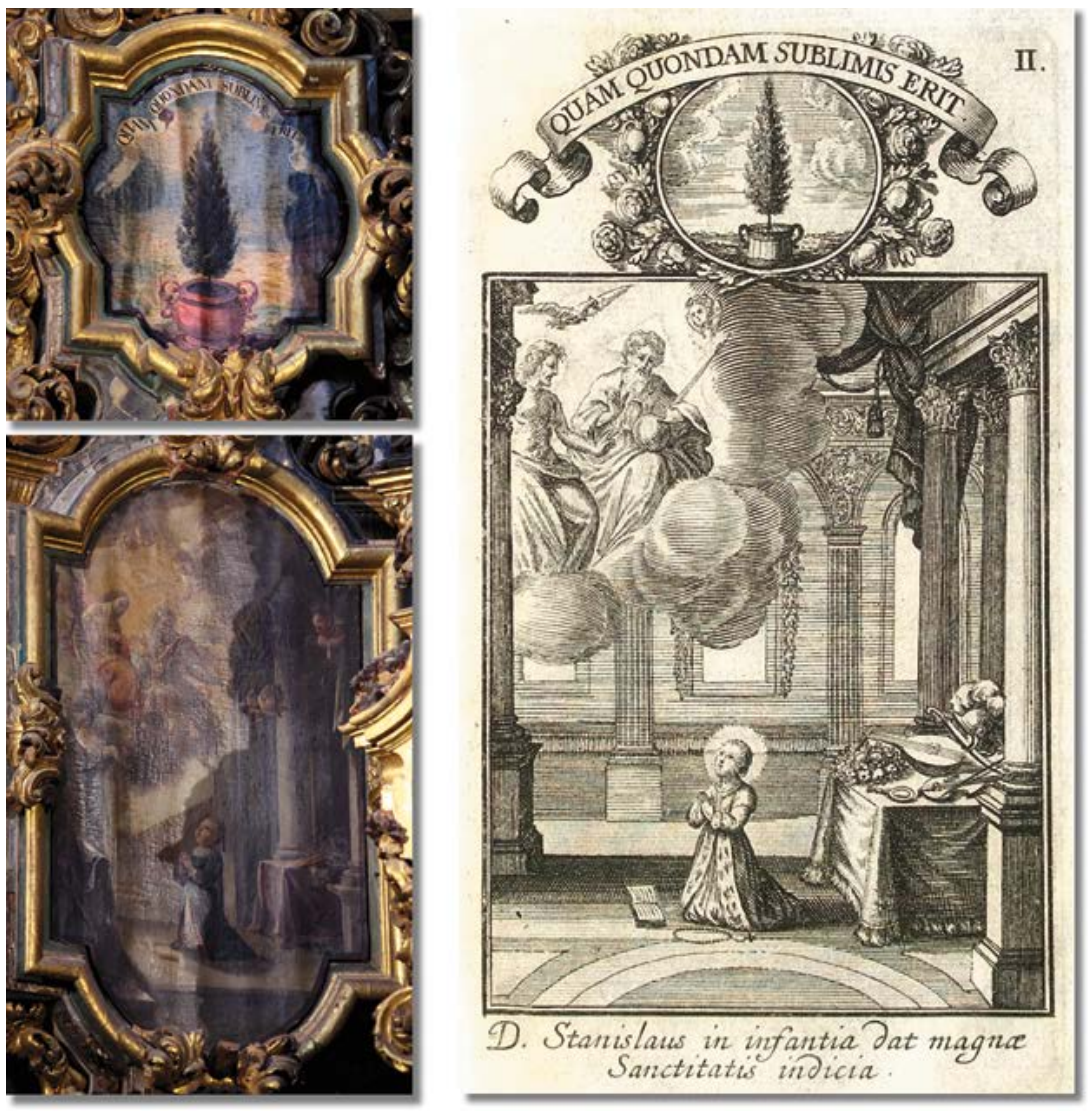

Fig. 3. Indicios de santidad en Estanislao niño: tipo pseudo-narrativo central de la calle izquierda, jeroglífico superior y estampa II.

dad $^{7}$. En el presente caso, la imagen de San Estanislao es objetivamente atemporal, puesto que éste se nos muestra como un bienaventurado celeste, con un efecto de ingravidez - de inspiración romana- destinado a fomentar la oración o contemplación mística.

La presencia del Niño Jesús en brazos de Estanislao es algo procedente de la historia terrena, basada en la visión de la Virgen María con el Niño, un tema procedente de las biografías. Dicho tema está presente en el lateral derecho de este mismo retablo, asunto sobre el que volveremos. Con todo, el Niño tenderá a convertirse en un atributo esencial de la imagen del santo, como podremos apreciar ya en grabados como el de Cornelis Galle ${ }^{8}$, o de Cornelis Martinus Vermeulen, a partir de Nicolas de Largillière ${ }^{9}$, así como en la pintura, con el lienzo de Miguel Cabrera (1761), correspondiente a la serie sobre santos jesuitas de la Universidad Iberoamericana de México.

La estructura significante de esta hornacina central se completa con dos clípeos situados en el centro de los estípites laterales. San Estanislao es flanqueado por el Salvador (izq.) y la Virgen (der.).

Alrededor de esta imagen, núcleo significante del retablo, se dispone todo un argumentario visual conformado por imágenes narrativas, reforzadas con emblemas que condensan la esencia discursiva de carácter moral o ejemplar que se pretende transmitir.

\footnotetext{
7 Ejemplo paradigmático de ello la imagen de San Bruno de Manuel Pereyra, incorporada a la hornacina central de un retablo de la Cartuja de Miraflores (Burgos), una imagen con cierto carácter de temporalidad que lo acercaba a la narración, entendida como la expresión de una acción concreta en un momento concreto: san Bruno aparece como sorprendido instantáneamente mientras ora ante el crucifijo que sostiene su mano. La noción de imagen conceptual, siguiendo a Gombrich, ha sido desarrollada en García Mahíques, 2009: 53 y ss. El tema fue retomado posteriormente para entenderlo más allá de la revolución griega (García Mahíques, 2011: 65-86).

${ }^{8}$ Cornelis Galle, 1586-1650. Amsterdam, Rijksmuseum, RP-P-1905-849.

9 1654-1709, Amsterdam, Rijksmuseum, RP-P-OB-15.7089.
} 


\section{Una vida santa}

Nos referiremos, en este apartado, a tres temas biográficos que han dado lugar a tres tipos iconográficos de carácter narrativo dispuestos en los tres espacios más importantes, en torno a la hornacina central, que por orden cronológico de acuerdo con el orden establecido en las fuentes literarias son: Estanislao niño en oración (lateral izquierdo), Visión de Santa Bárbara y comunión de manos de los ángeles (centro del ático) y Visión de la Virgen con el Niño (lateral derecho). Los dos tipos correspondientes a las calles laterales llevan cada uno dos jeroglíficos asociados.

\section{Indicios de santidad en Estanislao niño}

Corresponde a la calle lateral izquierda del cuerpo central del retablo. Lo conforma un lienzo que muestra a san Estanislao niño arrodillado, orante ante la Trinidad [fig. 3]. Se trata de un tipo iconográfico que responde estrictamente a una construcción imaginaria (pseudo-biográfica) de la infancia del santo, ya que de esta etapa de su vida las fuentes no dicen apenas nada. El eje discursivo radica en poner de relieve la vocación a la santidad de Estanislao desde niño, manifestada en la oración como actitud alternativa a las ocupaciones terrenas.

Esta imagen ha sido compuesta a partir del grabado correspondiente a la estampa II, de Dilinga. Lleva por letra: D. Stanislaus in infantia dat magnae Santitatis indicia [Estanislao da indicios de gran santidad en la infancia]. Puede parecer un episodio relativo a una visión concreta de la Trinidad, pero no es así. La presencia divina, así como la mesa llena de objetos, son solamente recursos correspondientes al ornatus de este apócrifo discurso. Se pretende poner de manifiesto la tendencia hacia la oración que desde pequeño experimentó Estanislao, quien a los 15 años, cuando estaba en Viena estudiando dedicaba largos ratos a orar, y —según el proceso de beatificación en declaración de su hermano Pablo - éste quedaba inconsciente, algo que ocurría especialmente en la iglesia de los jesuitas, aunque también una vez en el hogar paterno, en Pascua, cuando estaba sentado a la mesa con sus padres y otras personas ${ }^{10}$, lo cual ha dado pie a ser interpretado como arrobo místico. Es muy significativo el hecho de que a su espalda la mesa esté llena de objetos típicos de la vida terrena: instrumentos de música, flores, espejo, espada y yelmo militares..., un auténtico bodegón de vanitas, que debe interpretarse como las renuncias terrenas, algo que ha quedado reducido a la mínima expresión en la versión pictórica del retablo.

El jeroglífico superior, tomado de la misma estampa II de Dilinga, consta de un cedro plantado en un tiesto, y por mote: QUAM QUONDAM SUBLIMIS ERIT [Cuán alto será algún día]. Este mote, o lema, figura en la Anthologia scientiarum et artium de Bober ${ }^{11}$, en cuyo compendio de epigramas, sentencias, adagia, enigmas, etc., con referencia al cedro dice así: "Tenella Cedrus. Quan quondam sublimis erit!”. El pequeño cedro — con apariencia de ciprés - plantado aquí en un tiesto, significa que se espera un gran desarrollo en altura, ya que el cedro es, por excelencia, de acuerdo con la tradición, el árbol más elevado de todas las especies. Esta es justamente la cualidad sobre la cual se ha construido este jeroglífico, confirmado de tal modo por el comentarista de Dilinga ${ }^{12}$. Aparte de ello, el cedro es también, en los códigos de la retórica, un árbol noble e incorruptible, algo que expresa Boschius (II, 606) con el mote: "Incorrupta manet" [Permanece incorruptible $]^{13}$.

\footnotetext{
10 "'He devoted himself so completely to spiritual things that he frequently became unconscious, especially in the church of the Jesuit Fathers at Vienna. It is true,' added the witness, 'that this had happened at home to my brother at Easter when he was seated at table with our parents and other persons'”. (Catholic Enciclopedia, vol. 14.djvu/287: 245).

${ }^{11}$ Bober, 1809: 200.

12 Jesuitas, 1727: 8. "In parvo igitur jam súrculo regem arborum, in humili ramusculo procerae magnitudinis prodigium mirare, \& tecum, quàm quondam sublimis erit, tacitus exclama!’.

13 Boschius, 1702: 45. Para expresar Nobilitas, dice así: "Cedrus, putredinis expers. L. INCORRUPTA MANET. Menet".
} 

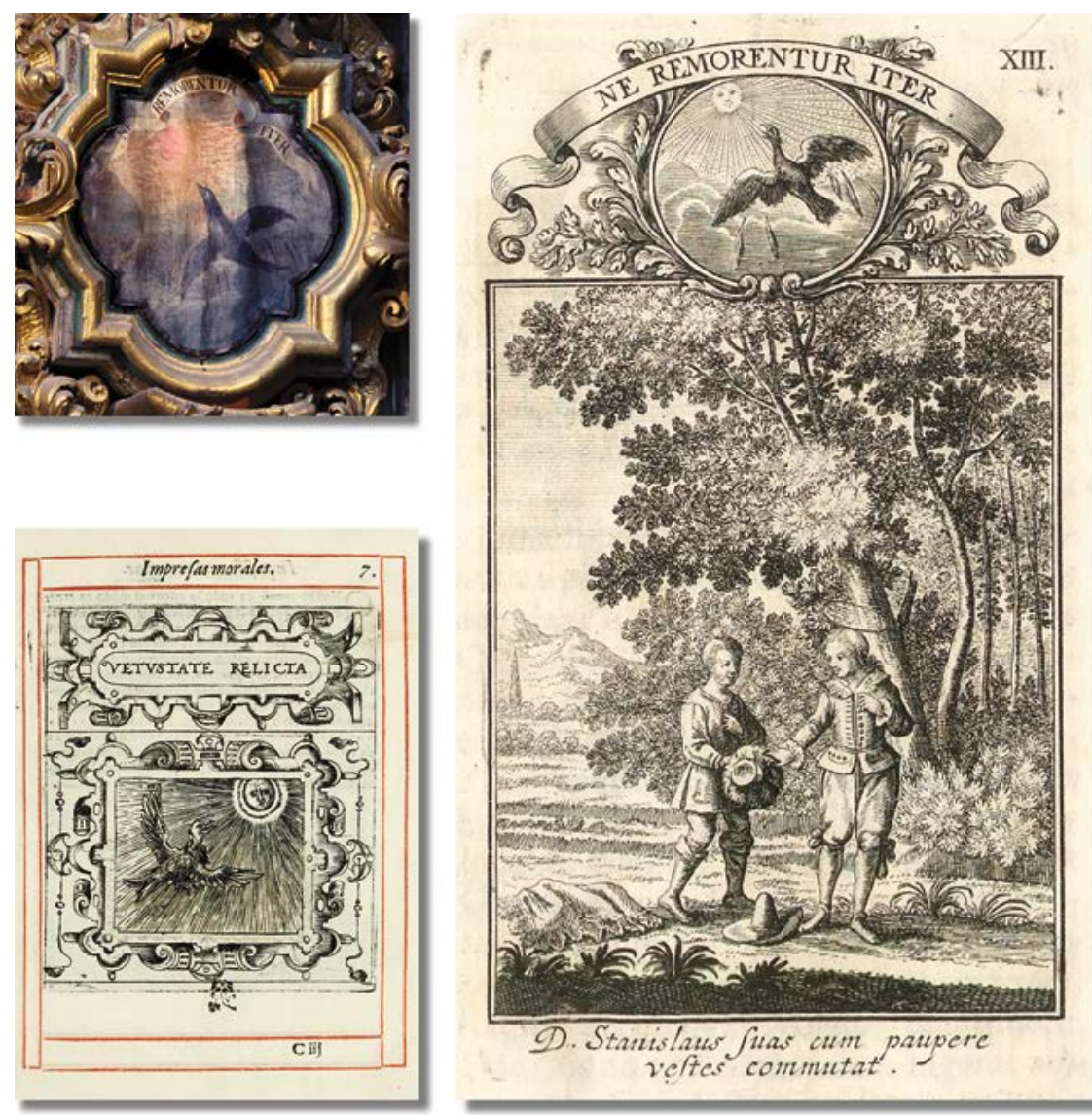

Fig. 4. Indicios de santidad en Estanislao niño: jeroglífico inferior, empresa VI de Juan de Borja y estampa XIII.

El jeroglífico inferior está tomado de la estampa XIII de Dilinga, que consta del águila que vuela hacia el sol y renueva su plumaje [fig. 4]. Por mote: NE REMORENTUR ITER. [Que no detengan su camino]. El comentarista ${ }^{14}$ alaba la preeminencia del águila entre las demás aves, y se basa en aquella propiedad según la cual ésta renueva su plumaje volando hacia el sol para quemar las viejas plumas con su calor. Pone en relación el águila con el carácter de Estanislao, que se desprendió de sus vestidos dándoselos a un pobre, imagen de renuncia a los bienes terrenos como el águila que se desprende de su viejo plumaje. El grabado porta el siguiente texto: D. Stanislaus suas cum paupere vestes commutat [Estanislao intercambia sus vestidos con un pobre]. En realidad, este hecho parece también apócrifo, ya que las biografías antiguas de san Estanislao solamente explican que se dirigió a pie desde Viena hasta Dilinga para solicitar a Pedro Canisio su entrada en la Compañía, y para ello se desprendió de sus ricas vestiduras, adoptando otras más corrientes para no llamar la atención en una peligrosa travesía.

Como es ya sabido, este tópico sobre el águila arranca de la Biblia en expresiones tales como "y tu juventud se renueva como la del águila" (Sal 103,5), o "a los que esperan en Yahvé, él les renovará el vigor, subirán con alas como de águilas, correrán sin fatigarse y andarán sin cansarse" (Is 40,31), encontrando ya la narración completa en el Fisiólogo, cuyo texto latino dice así: "al envejecer el águila, se le tornan de plomo las alas y se le cubren de tinieblas los ojos ¿Qué hacer entonces? Busca una fuente de agua, vuela por los aires hacia el sol, quema en él sus alas y la oscuridad de sus ojos, baja luego a la fuente, se baña tres veces en ella y queda rejuveneci-

\footnotetext{
14 Jesuitas, 1727: 75 y ss.
} 


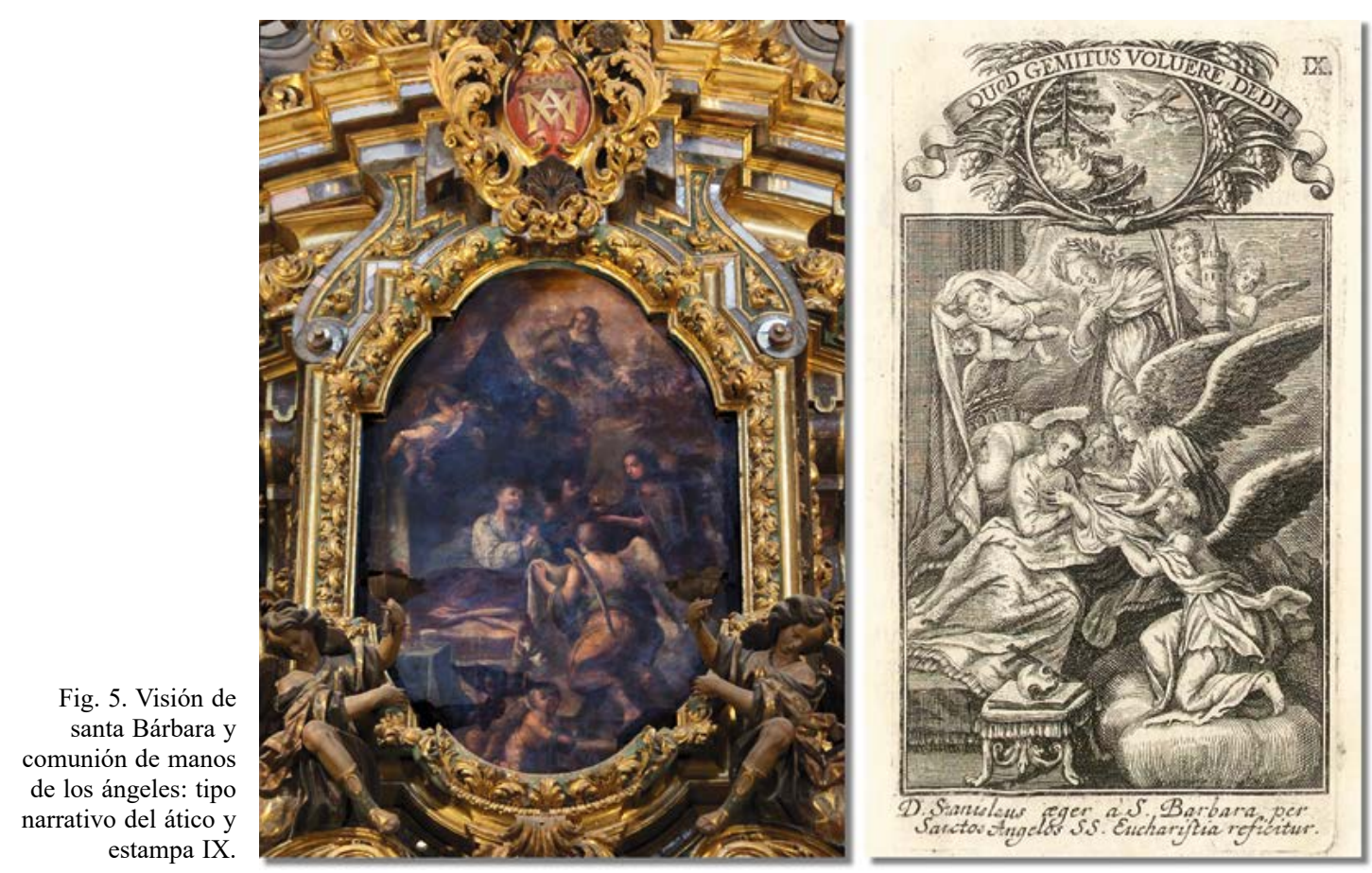

da y renovada" 15 . Dentro de la tradición emblemática, Juan de Borja se basa en esta leyenda para su empresa VI, que lleva por mote: "Vetustate relicta" [Dejada la vejez], en donde comenta: "lo mismo nos acontecerá si quisiéremos llegarnos tanto a nuestro Sol de Justicia, que nos abrase, y nos renueve" 16 . Boschius (I, 612), en dos jeroglíficos: "Del sol los rayos goza" y "Facie ad faciem" [Cara a cara], respectivamente, significará la muerte de una persona santa ${ }^{17}$.

Visión de santa Bárbara y comunión de manos de los ángeles

Corresponde al lienzo central del ático. Presenta icónicamente un episodio de la vida de san Estanislao inspirado también en la estampa IX del libro publicado por los jesuitas de Dilinga, aunque el pintor del retablo ha reorganizado la composición [fig. 5]. Santa Bárbara, en la parte superior, lleva palma de martirio. Ángeles infantes apartan las cortinas del dosel de la cama de Estanislao, a quien se aproximan dos ángeles mancebos, uno de ellos lleva la comunión al enfermo, mientras el otro, reverente y de espaldas al espectador, acerca con sus manos un paño. Cerca de la cama hay una mesa con utensilios cotidianos - en lugar de la calavera sobre un libro que aparece en el grabado-, y otros elementos portados por ángeles infantes, resaltando la azucena como atributo. En el grabado de origen, la inscripción al pie reza así: "D. Stanislaus aeger a S. Barbara per Sanctos Angelos SS. Eucharistia reficitur" [Estanislao enfermo es reconfortado con la santa Eucaristía por Santa Bárbara por medio de los Santos Ángeles]. Este lienzo no tiene ningún jeroglífico asociado, a pesar de que en la estampa sí lo lleva.

De acuerdo con las fuentes, este acontecimiento tuvo lugar en Viena en un momento en que Estanislao enfermó con peligro de morir, como cuenta Ribadeneira. Devoto de santa Bárbara, el

15 Fisiólogo, 1971: 8,46. Para mayor información de fuentes y tradición emblemática, véase García Arranz, 2010: 148 y ss.

16 Borja, 1998: 24.

17 Boschius, 1702: 43. “Aquila in solem intentis oculis. L. DEL SOL LOS RAYOS GOZA. Radiis solis perfruitur. Vel. FACIE AD FACIEM. Idem”. 

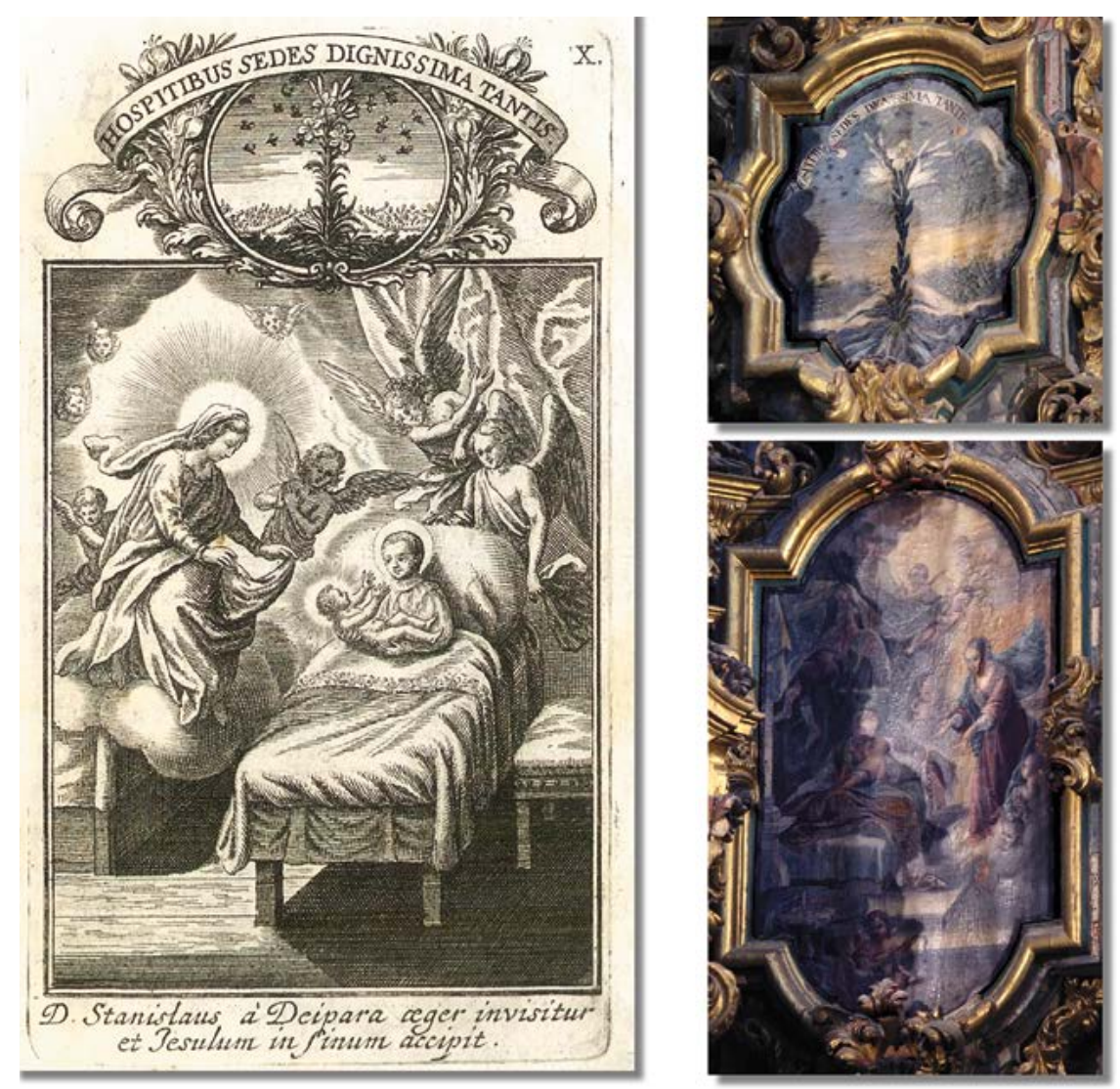

Fig. 6. Visión de la Virgen con el Niño: tipo narrativo central de la calle derecha, jeroglífico superior y estampa X.

joven se había encomendado a Dios por intercesión de la santa, quien se presentó en la estancia con dos ángeles que reverentemente portaban el santo Sacramento, de cuyas manos comulgó ${ }^{18}$. Sacchini, más sintético, viene a decir también lo mismo ${ }^{19}$. Por su parte, Bartoli reconstruye de un modo más novelado el acontecimiento añadiendo detalles de invención propia, haciendo intervenir incluso al preceptor Jan Bilinski, que por encargo familiar asistía a los dos hermanos Kostka en su estancia vienesa ${ }^{20}$.

Con todos estos precedentes literarios, importa señalar también que este tipo iconográfico se encuentra muy asentado en la tradición icónica de san Estanislao. Una de las primeras represen-

18 Ribadeneira, 1609: 4-5. "Venuto in articolo di morte desiderò intensissimamente in santo Sacramenti, \& in particolare l'Eucharistia per suo viatico; e come suisceratamente diuoto di S. Barbera si fidò non Dover far partenza senza esso, come si legge accadere a i diuoti di lei. Onde caldamente raccomandatosi à Dio con l'intercessione di detta Santa, ecco in vn tratto ad occhi veggenti entrare in camera Santa Barbera in mezzo a due Anglioli, che riuerentemente portauano il Sagramento Santissimo dell'Altare, per le cui mani con ineffabile dolcezza, e contento si communicò".

19 Sacchini, 1609: 17. "Nocte intempesta ipsa apparet S. Barbara, duoq[e]: Angeli in claro lumine, sacrosantam afferentes Hostia[m]: qui cum ad lectulum acessissent famelici egri, reuerenter ei porrexerunt".

${ }_{20}$ Bartoli, 1681: 34-35. "Così pregando, e piangendo, vna notte delle sette che il suo Aio Bilinski gli assistè continuo al letto vegghiando, e temendo che ciascuna non fosse l'vltima della vita di Stanislao; questi, tutto improuiso mouendosi, e riuolto a lui, con parole viue, e chiare, e in modo significante espressione di gran presteza, gli ordinò d'inchinarsi, e adorare il Venerabile Sacramento, che presente la Martire S. Barbara gli era portato: e in dicendolo, nulla ostante l'esser si finito di forze come chi è all'estremo, si leù̀ egli tutto da sè ginocchione, tre volte recitò il Domine non sum dignus, com'e vso nel riceuere della communione, e preso reuerentissimamente il corpo del Signore da vn de'due Angioli che gliel portarono, tutto si ricompose in atto e in sembiante di profondissima riuerenza". 
taciones, como ha señalado E. Ortega, es la realizada por Anton Wierix antes de su beatificación de facto $^{21}$. De hecho, siguieron otras representaciones grabadas posteriores, como la de Hieronymus Wierix ${ }^{22}$, o la de Cornelis Gall ${ }^{23}$, las cuales tienen en común el haber perdido el contexto donde este acontecimiento tuvo lugar: Estanislao enfermo en la cama. En todas estas versiones flamencas el acontecimiento tiene lugar en una estancia asimilable a un oratorio donde un reverente Estanislao recibe la comunión de rodillas.

\section{Visión de la Virgen con el Niño}

Corresponde al lateral derecho del cuerpo central. El lienzo nos presenta al santo enfermo en cama, visitado por la Virgen y recibiendo de ella al Niño Jesús [fig. 6]. Es un acontecimiento de la vida de Estanislao recogido en todas sus biografías, si bien hay que matizar los hechos para poder entender lo que muestra o concreta el tipo iconográfico.

Se basa en la estampa $\mathrm{X}$ del libro de los jesuitas de Dilinga, en cuya base leemos: " $D$. Stanislaus à Deipara aeger invisitur et Iesulum in sinum accipit" [Estanislao enfermo es visitado por la Madre de Dios y recibe en su seno a Jesús Niño]. También aquí la composición presenta algunas modificaciones respecto al grabado que no afectan a lo esencial: inversión respecto de su fuente inspiradora, gesto de la Virgen extendiendo sus manos, disposición de los ángeles más elaborada -interviniendo incluso ángeles músicos-, más otros elementos secundarios. Lo más característico de este tipo iconográfico es la colocación del Niño en brazos del enfermo, que en el lienzo se ha cuidado de un modo especial al aparecer ambos en diálogo místico por medio de las miradas, algo presente también en la imagen central de la hornacina, como acabamos de ver. Cabe suponer - no lo tenemos verificado - que la imagen de canonización de san Estanislao de Kostka debió ya de ser un tipo iconográfico basado en este acontecimiento. El hecho de que la Virgen haya depositado al Niño en sus brazos no es algo que conste como tal en las primeras biografías, prácticamente contemporáneas de su beatificación. Pedro de Ribadeneira especifica que fue visitado por la Madre de Dios con el Niño, que puso sobre la cama de modo que con su vista y presencia confortase al enfermo, gracias a lo cual éste comenzó a revitalizarse ${ }^{24}$. En parecidos términos se expresa también Sacchini ${ }^{25}$. En cambio, Bartoli, siete décadas más tarde, ofrece ya una percepción diferente del acontecimiento. Refiere que la Reina de los Ángeles se acercó a la orilla del lecho y no le bastó con consolarlo con su vista, dispuso sobre el lecho a su hijo "para que pudieran mu-

21 Ortega, 2018: 217. Anton Wierix, ca. 1604. Amsterdam, Rijksmuseum, RP-P-1907-3897.

22 Hieronymus Wierix, ca. 1619. Amsterdam, Rijksmuseum, RP-P-1898-A-19861.

${ }^{23}$ Cornelis Gall, 1625-1678. Amsterdam, Rijksmuseum, RP-P-1904-382.

${ }^{24}$ Ribadeneira, 1609: 5. El texto completo de este pasaje, lo describe así Ribadeneira, pasaje que incluye también el mandato por parte de la Virgen de que ingrese en la Compañía de Jesús: "Ne molto dopo glia aparue la Madre di Dio col figliuolino in braccio, il qua le posato sul letto talmente con la sua vista, e presenza confortò l'amalato, che incontanente cominciò à rinuigorire, e fuor di speranza altrui surse in breue del letto sano, e saluo: e la Madre di Dio prima di sparire gli disse, Vattene alla Compagnia di Giesù. Questi diuini fauori gli furono in diuersi tempi cauati di bocca da persone di spirito, delche accortosi egli s'accese di virginal rossore nel volto. Cresceua in tanto sempre via pii al Beato Stanislao il Desiderio d'entrare nella Copmpagnia, ricordandosi delle parole dettegli dalla Vergine, \& accogliendosi che i Padri lo tratteneuano con parole per esser egli per ancora d'età troppo tenera, non potendo più soffrire la dilazione, fece risoluzione tale, che potrebbe parere temeraria, se il feruore, e come si deue credere lo instinto dello Spirito Santo non lo scusasse; poscianche vna mattina dopo essersi confessato, e communicato spogliatosi de suoi vestiti ricchi, e nobili, riuestosi d'altri vili, è poueri, soletto \& a piedi con vn bastoncello in mano si pose iu viaggio alla volta d'Augusta [p. 5] per hauer vdito, che vi si trouaua il P. Pietro Canisio Provinciale della Compagnia di Giesù per quelle parti, dal quale speraua d'esser ricevuto, e se ciò non hauesse alla prima impetrato era risoluto, e ne fece anco voto di non ritornar mai più à casa de suoi, ma iui trattenersi limosinando a vscio ad vscio se fusse bisognato finche gli fusse fatta grazia di riceuerlo".

${ }_{25}$ Sacchini, 1609: 18. "Virgo Dei Mater, paruulum filium in sinu gestans praesens adsuit, consolans clientem suum, ac recreans: quem quo vberior suauitate profunderet, puellum IESVM in eiusdem lectulo collocavit”. 

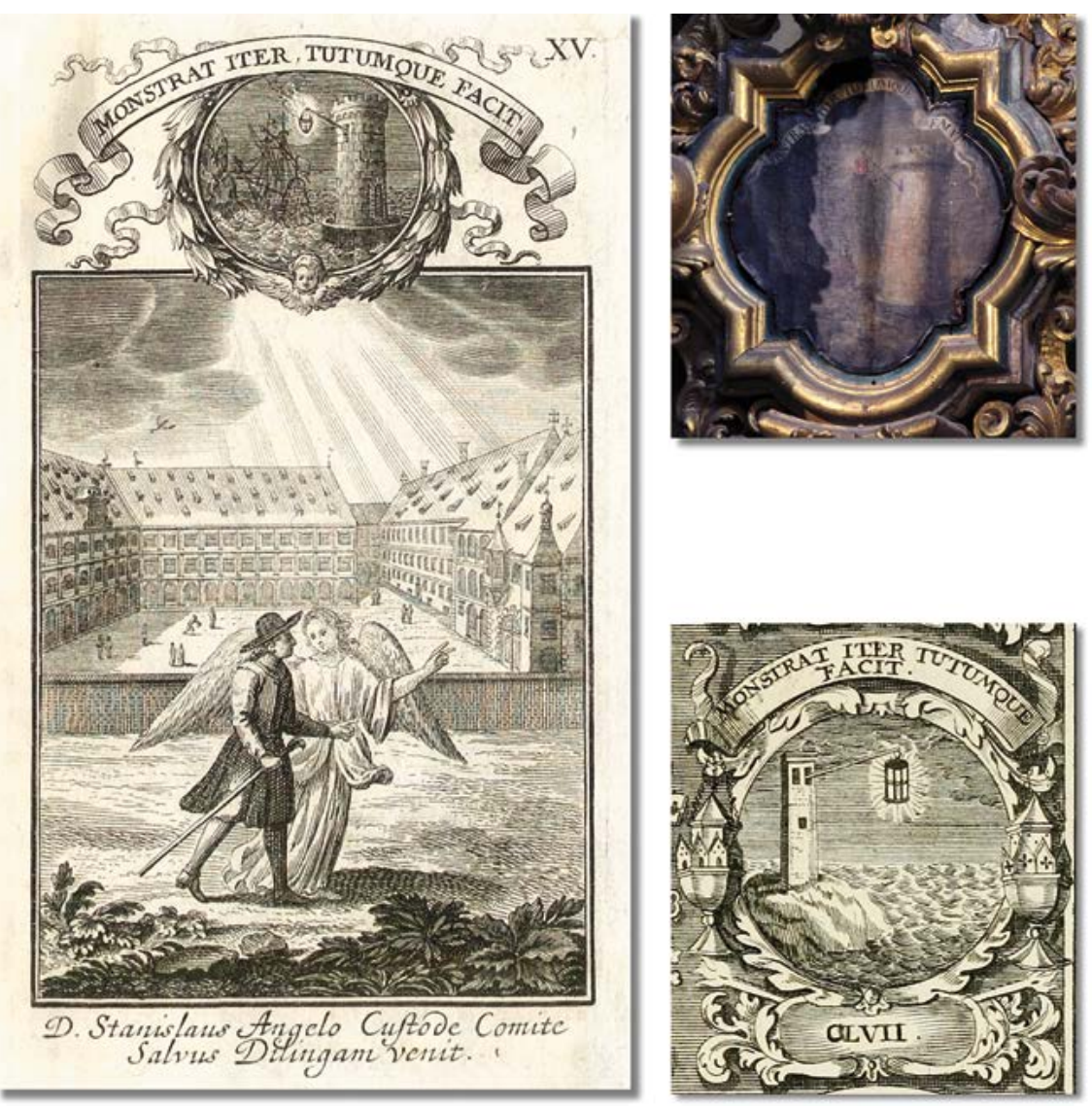

Fig. 7. Visión de la Virgen con el Niño: jeroglífico inferior, jeroglífico CLVII de J. Boschius y estampa XV.

tuamente abrazarse y juntar sus caras y sus corazones, él y Estanislao" 26 . Todo hace pensar, pues, que la creación del tipo iconográfico de san Estanislao con el Niño en brazos, bien ilustrando este episodio, bien como imagen conceptual del santo, debió de producirse a lo largo del siglo XVII.

El jeroglífico superior, que tiene también su fuente en la misma estampa X, consta de una azucena florida en medio del campo, a la que acuden las abejas. Por mote se lee: HOSPITIBUS SEDES DIGNISSIMA TANTIS. [Una mansión muy digna para tan altos huéspedes]. Los jesuitas, por medio de este jeroglífico de las abejas que acuden a libar las mieles de la azucena, quieren poner de manifiesto un paralelismo entre las dos virginidades: "Virgines cum virginibus, innocentes cum innocentibus", subrayando la pureza de Estanislao como receptáculo al que acuden María y Jesús. Con esta misma pictura, Boschius (I, 830) presenta un jeroglífico referido a las vírgenes religiosas, que admite tres posibles motes: "Virginei laus prima pudoris" [Alabanza primera del pudor virginal], "Neglectis caeteris" [Ignorados los demás] y "Virginitatis fecunda" [De la virginidad fecunda $]^{27}$.

${ }^{26}$ Bartoli, 1681: 37. "Peroche abbandonatane già ogni cura da'Medici, e d'hora in hora piu vicino al mancare, gli si mostrò tutto improuiso chiara e visibile col suo diuin figliuolo in braccio la Reina de gli Angioli tanto da lui teneramente amata, e diuotamente seruita, e fattaglisi tutta piaceuole fino alla sponda del letto, non le bastò consolarlo con la veduta, e con le amorose parole che pur douette ancor dirgli, ma gli dipose sopra'l letto il suo stesso figliuolo, sì che poderono scambicuolmente abbraciarsi, e appressare $i$ lor volti, e i lor cuori, egli es Stanislao".

27 Boschius, 1702: 58. "Apes ad Lilium advolantes. L. VIRGINEI LAUS PRIMA PUDORIS. Bela. / Vel: NEGLECTIS CAETERIS. Men. / Vel: VIRGINITAS FECUNDA”. 
El significado del lirio en relación con la virginidad, que se convertirá también en uno de los atributos de san Estanislao, se encuentra ya en el mundo antiguo (Tibul. I, 13-14), debiendo a P. Berchorius su codificación en la tradición cristiana. En tiempos modernos, Pierio Valeriano lo reconoce también como símbolo de la pureza, y por ejemplo Covarrubias (I, 5$)^{28}$ presenta la flor destroncada y rota como la pérdida de la virginidad, don irreparable. El lirio es atributo de la Virgen María y de muchos santos significando siempre esta misma virtud. En este sentido, el repertorio es muy abundante en todos los sentidos ${ }^{29}$.

El jeroglífico inferior consta de un faro que ilumina el mar, con un velero [fig. 7]. Por mote: MONSTRAT ITER TUTUMQUE FACIT [Muestra el camino y lo hace seguro]. Ha sido tomado de la estampa XV del mismo libro de Dilinga, correspondiendo al momento en que Estanislao llega a esta ciudad acompañado por su Ángel custodio. Según las biografías, Estanislao llegó a Dilinga a pie, vestido de un modo vulgar, donde será recibido por el provincial Pedro Canisio. En este sentido, este jeroglífico se corresponde con el inferior del lado izquierdo: allá iniciaba el camino, aquí concluye éste. El pie de la imagen reza de este modo: "D. Stanislaus Angelo Custode Comite Salvus Dilingam venit" [Estanislao llega seguro a Dilinga acompañado por el Ángel custodio], lo cual explica el sentido que tiene el faro como guía de la nave. Este mismo jeroglífico lo vemos también repetido, tanto en pictura como en lema, en el repertorio de Boschius (I, 157), significando a la Iglesia Católica y a los eclesiásticos ${ }^{30}$. El recurso al faro suele ser común en la emblemática aplicado al concepto de guía. Núñez de Cepeda, en su Empresa IX, presenta el faro con el mote "Nubila si obducant coelum, tamen excubat ignis" [Si acaso las nubes tapan el cielo, el fuego, sin embargo, vela], para significar que el prelado, debe ser como faro en la noche, no permitiendo que las tinieblas y la confusión desorienten a los fieles ${ }^{31}$.

\section{Espejo de novicios}

Dentro del orden biográfico, aunque superando este plano por tratarse de construcciones hagiográficas, pseudo-biográficas, o conceptuales fingiendo narración, el libro de los jesuitas de Dilinga introduce dos rasgos ejemplares de la personalidad de san Estanislao, dirigidos a la formación de los novicios. Éstos son: el don de la castidad y la devoción a la Virgen María, para lo cual se construyen dos concretos tipos iconográficos con sus respectivos jeroglíficos asociados que en este retablo de Sevilla aparecen separados: los tipos en la predela y los jeroglíficos en el ático. Pasemos a analizar cada uno de ellos.

\section{El don de la Castidad}

Lienzo oval del lado izquierdo de la predela [fig. 8]. Aparece san Estanislao, con hábito jesuita, orando ante un crucifijo a quien presenta una azucena, en presencia de la Virgen María, que se muestra sobre una nube, sin el Niño, acompañada de un ángel y con gesto de complacencia. Dos ángeles infantes, en la parte inferior, sostienen un bonete como atributo. Se trata de una adaptación - con composición invertida - de la estampa XXVI del libro de los jesuitas de Dilinga, en donde el tipo iconográfico aparece más elaborado. Aquí el santo lleva en sus manos no

\footnotetext{
${ }^{28}$ Covarrubias, 1610: 5.

29 Para una consideración del lirio en todas sus principales líneas significantes, véase García Mahíques, 1991: 413374, y más específicamente referido a la virginidad o castidad: García Mahíques, 1988: 66-68.

${ }^{30}$ Boschius, 1702: 13. "Pharus. L. MONSTRAT ITER TUTUMQVE FACIT. Vel: CURSUM DIRIGIT Syll. Men".

31 García Mahíques, 1988: 60-63. En el estudio de esta empresa se ofrece información varia sobre la proyección del faro en la emblemática.
} 

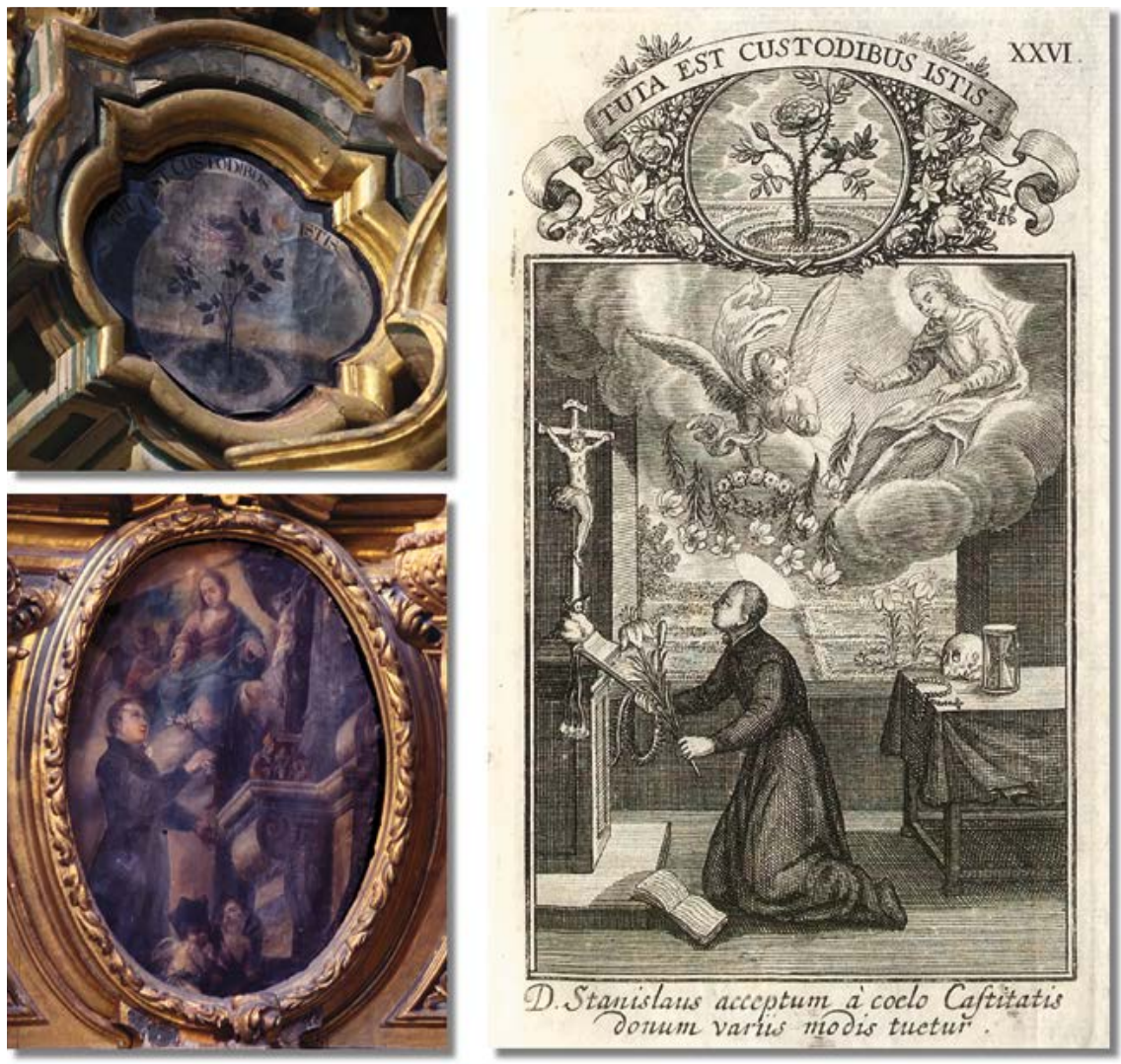

Fig. 8. El don de la Castidad: tipo pseudonarrativo de la predela, jeroglífico del ático y estampa XXVI.

sólo el lirio, sino también objetos de disciplina corporal, un libro abierto en el suelo, una mesa con un rosario, una calavera y un reloj de arena - componiendo una vanitas. Al fondo, la Virgen desciende de una nube en medio de una lluvia de azucenas con un ángel portador de una corona de flores. Tras la ventana, en el huerto, se divisan también azucenas plantadas. La inscripción al pie revela el sentido: "D. Stanislaus acceptum à coelo Castitatis donum variis modis tuetur" [Estanislao protege con recursos varios el don de la Castidad, muy grata al Cielo]. El lirio blanco, o azucena, que sostiene Estanislao en su mano es el atributo de la virginidad o la castidad, como hemos tratado anteriormente en el emblema de la azucena y las abejas. En el lienzo, Estanislao hace ademán de ofrecer el lirio a Cristo crucificado, lo que podría ser interpretado como ofrenda, algo que no consta como tal en el grabado de origen, en donde la Castidad es un don que el santo procura conservar mediante la oración y las disciplinas - omitidas en el lienzo. La oración ante Cristo crucificado fue algo que a lo largo de su vida practicó con frecuencia, incluso en el mismo momento de su muerte tuvo un coloquio con el crucifijo, como señaló detalladamente Ribadeneira ${ }^{32}$.

El jeroglífico correspondiente, situado en el ático, presenta una rosa, en medio de un arriate circular, armada toda de espinas. Por mote leemos TUTA EST CUSTODIBUS ISTIS [Con esos guardianes está segura]. De acuerdo con la explicatio symboli que se hace en este libro, la gratísima rosa - flor también relacionada con la Virginidad - se protege por medio de las

32 Ribadeneira, 1609: 13. “(...) \& in questo chiese il Crocifisso, il qual tenendo in mano, e mirándolo con molto affetto di diuozione sua, e de gli astanti venne dicendo insieme con loro varie orazioni, e specialmente quella di $S$. Innocenzio, che contiene la memoria di tutta la passione del Nostro Signore Giesù Cristo. Et dopo d'hauere i Padri cessato, incominci'ò egli solo a fare vn diuoto coloquio col Crocifisso secondo che il feruore, e lo Spirito santo gli suggeriua; E prima ringraziò Dio di ciascun benefizio, che gli hauea fatto; poi lo pregò gli perdonasse i peccari, e riceuesse l'anima sua in Paradiso (...)". 
Fig. 9. Devoción a María: tipo pseudonarrativo de la predela, jeroglífico del ático y estampa XXV.
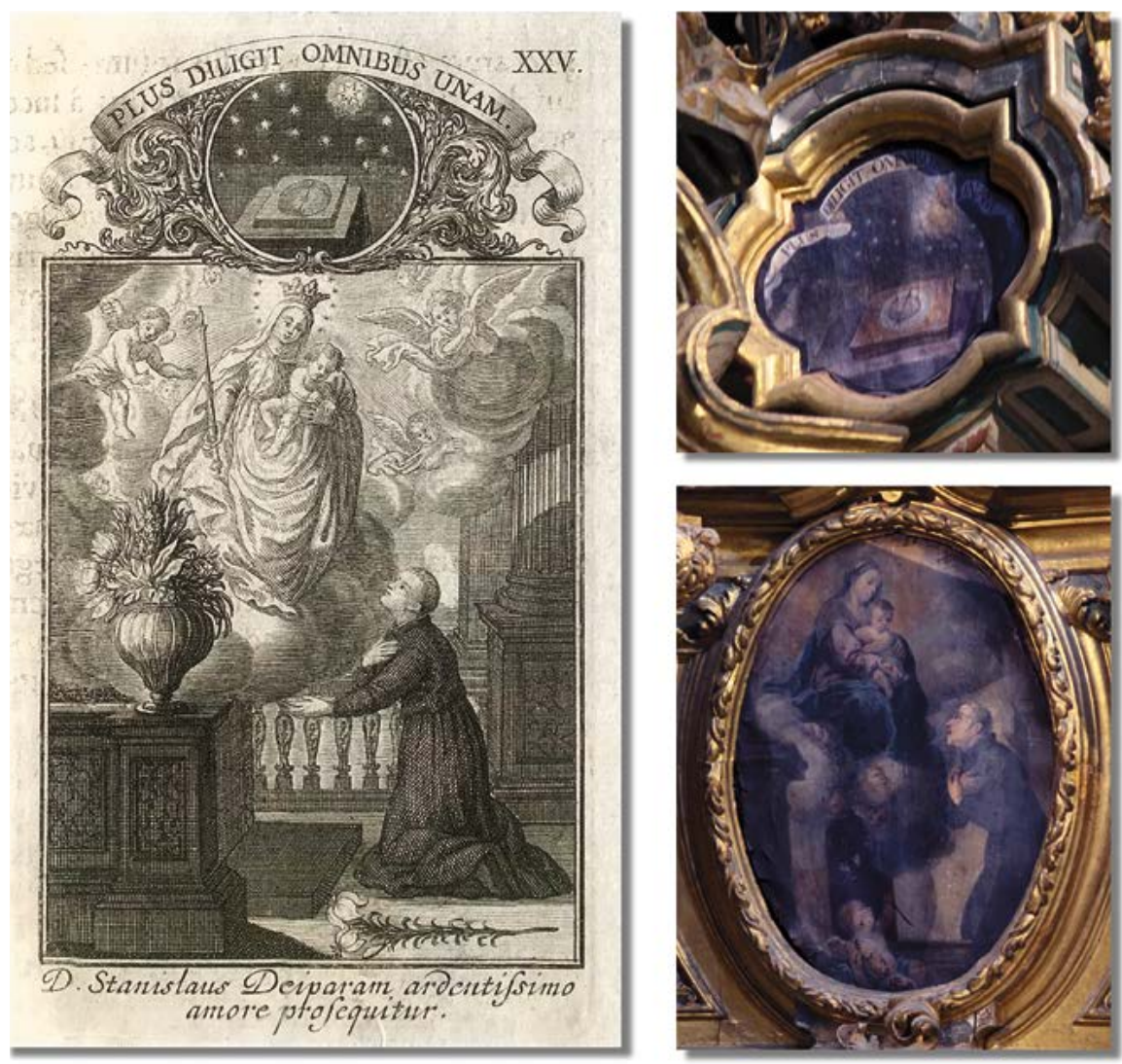

espinas. En efecto, la rosa, que ha llegado a ser vehículo retórico de muy diversos conceptos, uno de ellos, desde antiguo, es el de la Virginidad, en concreto la imagen de la rosa dentro de un jardín cerrado, protegida por tapias o por setos. Lo podemos ver en Cátulo que la alaba como flor secreta en los huertos cercados, ignota al rebaño, no arrancada por ningún arado, deseada... (Carm. 62, 39-47). Tal cosa fue emblematizada por P. Maccio (emb. LXVII), que presenta un jardín cercado con "Insignia virginum" [Atributo de las Vírgenes] por mote. En el epigrama explica que la rosa, protegida por las espinas, se mantiene lejos de fieras, pájaros, ganados errantes y manos rapaces, mas si se deja tomar por mano injuriosa, pierde todo su perfume y honor ${ }^{33}$. El mote empleado en el jeroglífico de los jesuitas de Dilinga lo podemos hallar también en otro jeroglífico de Boschius (I, 262), no reproducido en el repertorio de láminas, descrito como: Conchylium inter canes marinos [Concha entre canes marinos]. Tiene sentido como "custodia de las vírgenes", de modo semejante a cómo la concha protege a la almeja de sus depredadores ${ }^{34}$. La concha, pues, tiene el mismo significado de protección, equi-

${ }_{33}$ Maccio, 1628: 272-273. "Spinis en rosa stat minax acutis, / Et tuta, haud fera, non auis, rapaxuè / Accedit manus, aut greges a dire / Audent, asperioribus rubetis / Nam munita suo nitet colore. / Talem, cruda viro puella, temet / Serues, clausa tuo rigore, amantes / Pellas blandiloquos, procaciores, / Excludas procul impudica verba, / Nec donis animum sinas moueri / Mollem, nec precibus periculosis. / Decerpta si quidem rosa nihil moz / Cum sit vilius, ac minus decorum, / An non virgineus pudor, venustas / Formae deciderit, leposque ¿non ne / Arescet tuus ille flos reuulsus?". Para otros ejemplos emblemáticos en donde la rosa significa la virginidad, y para un panorama general sobre los diferentes significados que adquiere la rosa en la tradición retórica y en la emblemática, véase García Mahíques, 1991: 684-737.

34 Boschius, 1702: 273. "Virginitatis custodia. Conchylium inter canes marinos. L. TUTA EST CUSTODIBUS ISTIS." Por canes marinos, o perros de mar, podemos entender aquellos piratas (sea dogs) que en tiempos de Isabel II de Inglaterra surcaban los mares. 
valente a las espinas en la rosa, así como a la cerca o arriate que se aproxima al concepto de hortus conclussus.

\section{Devoción a María}

Se trata del homólogo lienzo oval situado en el lado derecho de la predela [fig. 9]. Aquí san Estanislao, también con hábito jesuita, ora ante la Virgen con el Niño que se muestra sentada entre las nubes, como si hubiera descendido del Cielo. Un ángel infante, debajo, alza con su mano la azucena, atributo del santo. Se inspira en la estampa XXV del libro de Dilinga, en donde los cambios obedecen solamente a aspectos compositivos y formales, sin observar variación alguna respecto a su tipología iconográfica, cuyo sentido es aclarado en la inscripción al pie: "D. Stanislaus Deiparam ardentissimo amore prosequitur" [Estanislao contempla con ardentísimo amor a la Madre de Dios]. Es evidente que se trata de una construcción visual imaginaria o pseudo-biográfica, aunque en las biografías contemporáneas no faltan alusiones al afecto de Estanislao hacia la Virgen María, como objeto de devoción en sus oraciones. P. de Ribadeneira afirma que estaba tan desprendido del afecto a sus parientes, que no quiso llamar padre sino a su Creador, ni quiso tener otra madre que la Virgen María con quien tenía un trato tierno y afectuoso ${ }^{35}$.

El jeroglífico asociado, situado también aquí en el ático, tiene por pictura una brújula orientada hacia la estrella polar en medio del firmamento, y por mote: PLUS DILIGIT OMNIBUS UNAM [La quiere a ella sola más que a ninguna], con una fácil interpretación aclarada en la prosa correspondiente del libro de Dilinga: María como Stella Maris, hacia la cual se orienta la aguja magnética de los navegantes para buscar puerto seguro, así Estanislao se orienta hacia el puerto seguro de la Compañía de Jesús por medio de la Virgen. En el fondo, se trata de una réplica de la visión de la Virgen con el Niño cuando estaba enfermo en Viena, momento en el que María le ordena ingresar en la Compañía, como hemos señalado anteriormente.

El concepto de la estrella polar o Stela Maris referido a María, tiene un origen medieval, encontrándose ya en Pascasius Readbertus del siglo IX, quien se refiere a María como estrella que guía al navegante en el camino hacia Cristo, para no zozobrar en medio de la tormenta marina. A esta época se remonta también el himno Ave Maris Stela, cantado en el oficio de vísperas en las fiestas marianas. Está por hacer aún un estudio específico de esta tipología mariana. Como precedentes emblemáticos, tenemos también aquí el de Boschius (I, 334), quien presenta en su repertorio un jeroglífico con esta misma pictura con el mote "Polum non deserit unquam" [El Polo (la polar) jamás desampara], que refiere a san Francisco de Sales ${ }^{36}$.

\section{Complementos}

El retablo se completa con unas imágenes no relacionadas directamente con san Estanislao de Kostka que, por algún motivo circunstancial, se decidió incorporar en cada lado del ático, acompañando a la Visión de Santa Bárbara y comunión de manos de los ángeles. Se trata de San Isidoro, a la izquierda, y San Juan Francisco Régis, a la derecha.

\footnotetext{
35 Ribadeneira, 1609: 10. "Era tanto staccato dall'affezione de parenti, che niuno altro volse mai chiamare con nome di padre, che Dio suo creatore, ne volle hauere altra madre, che la Beata Vergine Madre di Dio, à cui portaua si tenero affetto, che pareua nella diuozione di lei tutto si dileguasse, di questo spesso ragionaua, e la vita di lei meditaua".

36 Boschius, 1702: 24. "Eadem ejusdem. Pyxis náutica cum stella Polari. L. POLUM NON DESERIT UNQVAM".
} 

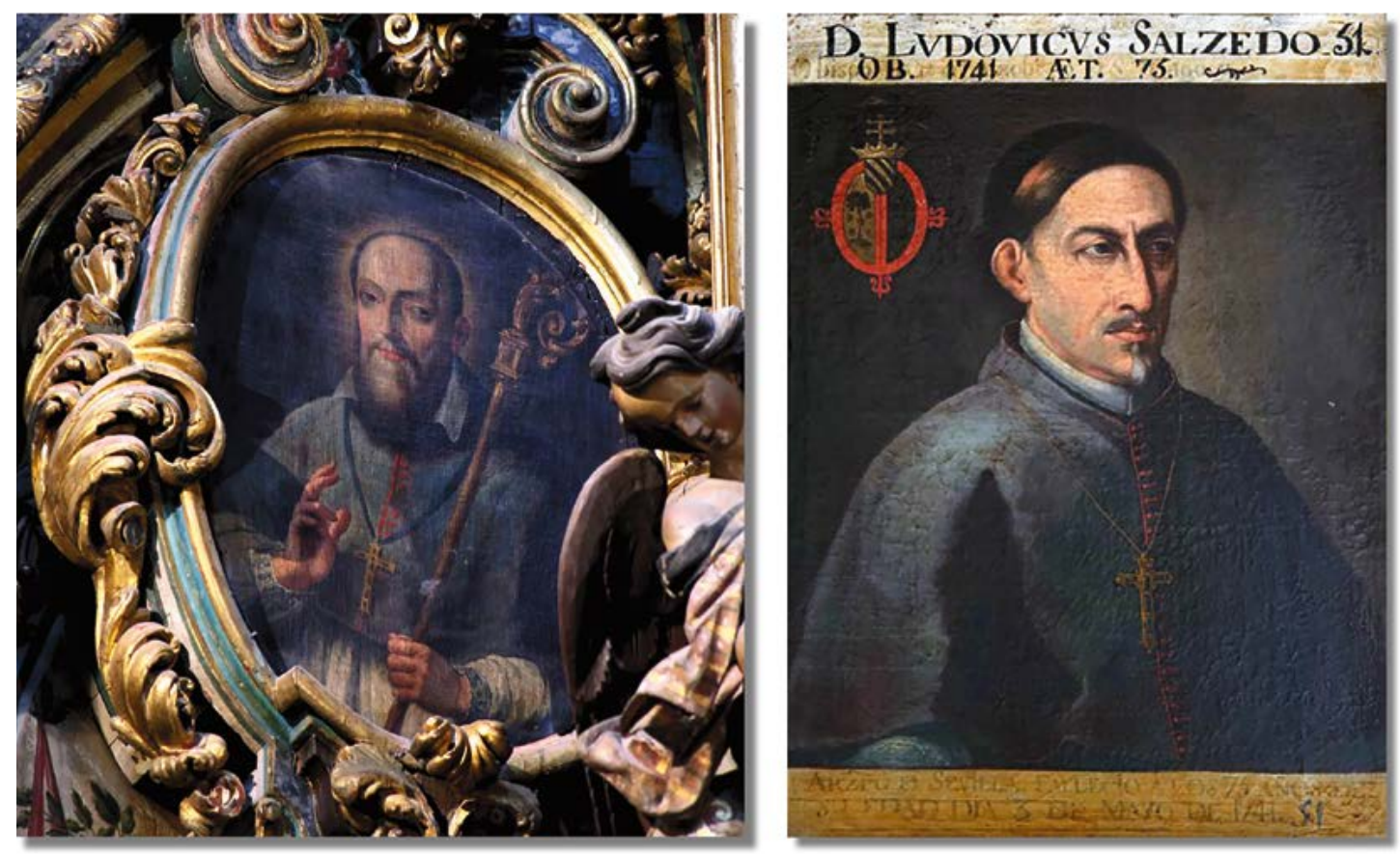

Fig. 10. Imagen conceptual de san Isidoro de Sevilla.

Retrato de Luis de Salcedo y Azcona, Arzobispo de Sevilla.

\section{San Isidoro de Sevilla}

Es una imagen conceptual del santo arzobispo de Sevilla ${ }^{37}$, y tanto es así que su atemporalidad nos lo hace percibir como un santo moderno [fig. 10]. Porta muceta gris con botonadura roja, exactamente como el retrato contemporáneo de Luis de Salcedo y Azcona, arzobispo de Sevilla (1723-1741), cuyo escudo figura en el coronamiento del retablo de san Francisco de Borja ${ }^{38}$. Lleva báculo episcopal y bendice con su mano derecha. San Isidoro había sido nombrado Doctor de la Iglesia en 1722 por el papa Inocencio XIII, lo cual debió motivar que fuese celebrado incorporándolo al retablo.

\section{San Juan Francisco Régis}

Se trata también de una imagen conceptual de este santo jesuita [fig. 11]. El lienzo es una de las imágenes de este santo jesuita que parten del grabado compuesto por Jean François $\mathrm{Cars}^{39}$, como la realizada por Domingo de Vasconcellos (s. XVIII, Iglesia de S. Ignacio, Bogotá). Régis fue beatificado el 18 de mayo de 1716 por Clemente XI, y canonizado el 16 de junio de 1737 por Clemente XII. De acuerdo con la cronología del retablo (ca. 1733), esta imagen se debió de hacer cuando aún era beato ${ }^{40}$. Un grabado de su efigie firmado por Hipó-

${ }^{37}$ Ha llegado a ser identificado con san Roberto Bellarmino, algo que no puede sostenerse debido al hecho de que fue cardenal $-\mathrm{y}$ lo debería reflejar la indumentaria-, y sobre todo porque fue beatificado (15 de abril de 1923) y canonizado (29 de junio de 1930) por Pío XI.

38 Sobre el mecenazgo artístico del arzobispo Salcedo y Azcona: Morales Martínez,1982.

39 Jean François Cars, 1715. París, BnF, Ec 5b in-fol.

40 También en estos momentos (1733) estarían inacabados los cuatro retablos menores situados en los machones que sostenían la cúpula (Ravé, 2010: 129), entre los cuales está precisamente el dedicado a san Juan Francisco Régis. 

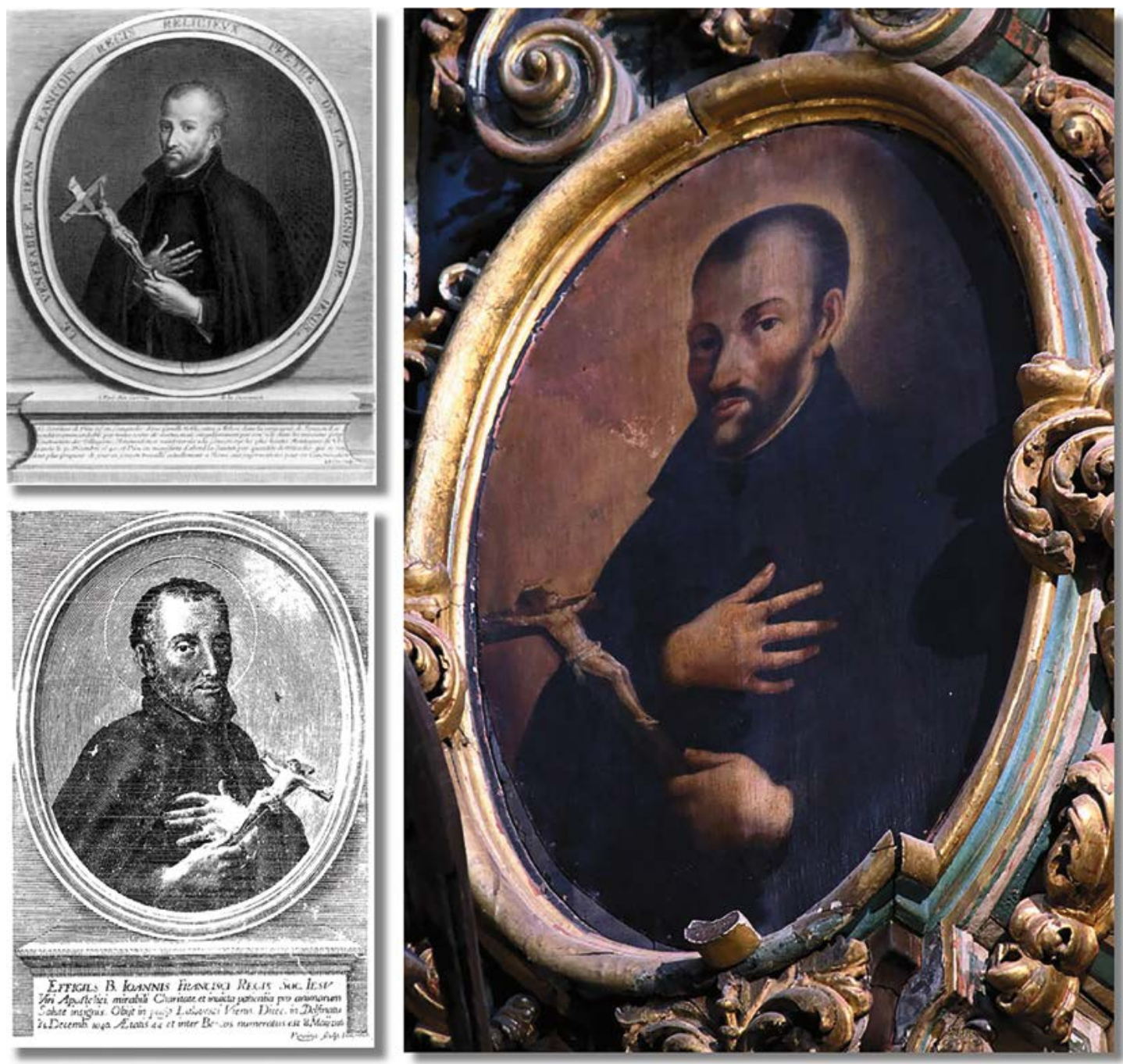

Fig. 11. Imagen conceptual de san Juan Francisco Régis: ático del retablo y estampas de Jean François Cars (1715) e Hipólito Rovira (1716).

lito Rovira en Valencia, inspirado sin duda en el de Cars - con una composición invertida respecto del grabado francés-, encabeza el libro sobre las fiestas de beatificación organizadas por el Colegio jesuita e Granada ${ }^{41}$, posible fuente directa de la pintura del retablo por las características fisonómicas. Probablemente, en el momento en que se decidió incorporar esta efigie al retablo aún no estaría planificado el dedicado a Régis en esta misma iglesia, dentro de los cuatro retablos menores, aludidos anteriormente, situados en los machones que sostienen la cúpula.

El retablo dedicado a san Estanislao de Kostka tiene como coronamiento el anagrama de María y un lienzo oval con el lirio blanco o azucena, atributo del santo, que hemos observado en otras partes del retablo.

41 Jesuitas, 1716. 


\section{BIBLIOGRAFÍA}

Anónimo (1731): Breue noticia de las sumptuosas fiestas i dedicación del Templo de San Luis, casa de probación de la Compañia de Jesús en el Hispalense emporio. Sevilla: Imprenta de las Siete revueltas.

Bartoli, D. (1681): Compendio della vita del B. Stanislao Kostka della Compagnia di Giesu composto dal Padre (...), Roma: a spese del Tinassi.

Bober, J.N. (1809): Anthologia Scientiarum et atrium auctore Joanne Nepom. Bober. Tom. Primi. Pars prima. Regiomonti.

Borja J. (1998). Empresas Morales, [ed. al cuidado de R. García Mahíques]. Valencia: Ajuntament de València.

Boschius, J. (1702): Symbolographia Sive De Arte Symbolica Sermones Septem. Quibus accessit Studio \& Operâ Ejusdem Sylloge Celebriorum Symbolorum In Qvatvor Divisa Classes Sacrorum, Heroicorum, Ethicorum, Et Satyricorum Bis Mille Iconismis Expressa. Augsburgo: Ioannem Casparum Bencard.

Busto, P. del (1731): Los tres templos del Señor. Oracion Panegyrica, que en el dia del Gloriosissimo San Estanislao de Kostka, uno de los tres, con que la Casa de Probación de San Luis, Noviciado de la Compañia de Jesús, celebró la solemne dedicación de su nuevo templo, dixo el [...]. Sevilla: Imprenta Castellana y Latina de Diego López de Haro.

Camacho Baños, A. (1935): El templo de San Luis de Sevilla. Sevilla: Diputación de Sevilla.

Camacho Martínez, R. (1989): "La iglesia de San Luis de los franceses en Sevilla, imagen polivalente". En: Cuadernos de Arte e Iconografia, 3, pp. 202-213.

Covarrubias, S. (1610): Emblemas morales. Madrid: Luis Sánchez.

Banda y Vargas, A. de la (1977): La iglesia sevillana de San Luis de los franceses. Sevilla: Diputación de Sevilla.

Banda y Vargas, A. de la (2004): "La pintura del patrimonio de la Compañía de Jesús en la provincia de Andalucía". En: F. García Gutiérrez (coor.), El arte de la Compañia de Jesús en Andalucía (1554-2004). Córdoba: Publicaciones Obra Social y Cultural Cajasur.

Fisiólogo (1971): El Fisiólogo, bestiario medieval. [Introducción y notas de Nilda Guglielmi y trad. castellana de M. Ayerra Redin]. Buenos Aires: Editorial Universitaria.

García Arranz, J.J. (2010): Symbola et Emblemata Avium. Las aves en los libros de emblemas y empresas de los siglos XVI y XVII. A Coruña: SIELAE / Sociedad de Cultura Valle Inclán.

García Luque, M. (2017): "La impronta de Murillo en la escultura sevillana del siglo XVIII”. En: Benito Navarrete Prieto (dir.): Murillo y su estela en Sevilla. Sevilla: Ayuntamiento de Sevilla-ICAS.

García Luque, M. (2018): "Dibujos de Duque Cornejo en el Álbum Jaffe (I): la colección del Metropolitan Museum of Art”. En: Philostrato. Revista de Historia y Arte, no 3, pp. 59-84. (En: http://doi.org/10.25293/philostrato.2018.13 [30/01/2020]).

García Mahíques, R. (1988): Empresas Sacras de Núñez de Cepeda. Madrid: Tuero.

García Mahíques, R. (1991): Flora Emblemática. Aproximación descriptiva del código icónico, València: Universitat de València. (En: http://roderic.uv.es/handle/10550/38526?show=full [30/01/2020]).

García Mahíques, R. (2009): Iconografia e iconología (vol, 2), Cuestiones de método. Madrid: Ed. Encuentro.

García Mahíques, R. (2011): "Imagen conceptual e imagen narrativa”. En: Rafael Zafra / José Javier Azanza (eds.): Emblemática Trascendente. Pamplona-Valencia: Anejos de Imago, revista de Emblemática y Cultura visual.

Gómez Piñol, E. (2004): "Retablos y esculturas de las iglesias jesuíticas en Andalucía: del clasicismo trentino al esplendor barroco del teatro sacro". En: F. García Gutiérrez (coor.): El arte de la Compañía de Jesús en Andalucía (15542004). Córdoba: Publicaciones Obra Social y Cultural Cajasur.

Herrera García, F. (2010): "La arquitectura de retablos sevillana en torno al lustro real, patrocinadores y teatralización del espacio religioso”. En: N. Morales / F. Quiles (eds.): Sevilla y Corte. Las artes y el lustro real (1729-1733). Madrid: Casa de Velázquez.

Jesuitas [1716]: Festivas demonstraciones, con que el Collegio de la Compañia de Jesus de Granada solemnizò los sagrados cultos, que decretò la Santidad de N.SS. Padre Clemente X. En la beatificacion del nuevo Apóstol de Francia el V. Padre Juan Francisco Regis [...]. Granada: Imprenta de la SS. Trinidad, por Francisco Domínguez.

Jesuitas (1727): Sancti Stanislai Kostka S.J. Vita iconismis, symbolis, doctrinis moralibus illustrate, ac ejusdem divi sacris, apotheoseos, honoribus secundis typis denuo consecrate a Devotissimo Convictu Dilingano acessit Brevis Epitome Vitae, Miraculorum, Beatificationis, ac Canonizationis ex Constitutione SS. PP. Benedicti XIII. Authenticè desumpta. Cum Licentia Superiorum. Dilinga: Formis Joan. Ferd. Schwertlen, Episcop. Princ. Aulae, \& Civit. Typographi.

Maccio, P. (1628) : Emblemata. Bolonia: Clemens Ferronius excudebat.

Martínez del Valle, G. (2017): “Cuatro dibujos atribuibles a Duque Cornejo”. En: Archivo Hispalense, 303-305, 100, pp. 439-443.

Morales Martínez, A. J. (1982): “Las empresas artísticas del arzobispo D. Luis Salcedo y Azcona”. En: Homenaje al prof. Dr. Hernández Díaz. Sevilla: Universidad de Sevilla.

Morales Martínez, A. J. (2012): “La arquitectura jesuítica en Andalucía. Estado de la cuestión”. En: La arquitectura jesuitica. Actas del Simposio Internacional, Zaragoza, 9, 10 y 11 de diciembre de 2010, pp. 327-354.

Ortega Mentxaca, E. (2018): Ad maiorem Dei gloriam. La iconografia jesuitica en la antigua provincia de Loyola (15511767). Bilbao: Universidad del País Vasco.

Ravé Prieto, J.L. (2010): San Luis de los Franceses. Sevilla: Diputación de Sevilla (col. Arte Hispalense, nº 89). 
Ribadeneira, P. (1609). Compendio della vita del Beato Stanislao Kostka, della Compagnia di Giesù. Estrato dalla Vita del Reuerendiss. P. Francesco Borgia, che fù Duca di Gandia, e poi Generale di detta Compagnia di Giesù. Composta per [...]. Brescia: Figliuoli di Vincenzo Sabbio.

Rodríguez SG. de Ceballos, A. (2004): “Arquitectura y arquitectos en la en la provincia jesuítica de Andalucía”. En: F. García Gutiérrez (coor.): El arte de la Compañia de Jesús en Andalucía (1554-2004). Córdoba: Publicaciones Obra Social y Cultural Cajasur.

Sacchini, F. (1609): Vita B. Stanislai Kostkae Poloni e Sociatate Iesv [...]. Ingolstadt: Adami Sartorii.

Ubaldini, U. (1890-1897): "Vita et miracula S. Stanislai Kostkae". En: Analecta Bollandiana, IX-XVI.

Fecha de recepción: 31-I-2020

Fecha de aceptación: 12-V-2020 